\title{
Hubungan antara Kegiatan Bermain Maze dengan Kecerdasan Visual-Spasial Anak Usia Dini
}

\section{Yulia Rachmawati}

Pendidikan Islam Anak Usia Dini, Universitas Islam Negeri Sunan Gunung Djati Bandung Jalan Soekarno Hatta Cimincrang Gedebage Bandung 406294

Email: yuliarachmawati175@gmail.com

Naskah diterima: 23 Agustus 2019, direvisi: 20 September 2019, diterbitkan: 27 September 2019

\section{Abstrak}

Penelitian ini bertujuan untuk mengetahui realitas hubungan antara kegiatan bermain maze dengan kecerdasan visual-spasial anak usia dini di Kelompok A RA Al-Wafi Panyileukan Bandung. Penelitian ini menggunakan pendekatan kuantitatif dengan metode deskriptif. Subjek dalam penelitian ini adalah anak Kelompok A RA Al-Wafi Panyileukan Bandung Tahun Ajaran 2018/2019 yang berjumlah 25 orang. Instrumen yang digunakan adalah lembar observasi yang telah diuji validitas menggunakan rumus korelasi Product Moment dan reliabilitasnya menggunakan rumus Alpha. Instrumen Kegiatan Bermain Mąe memiliki 36 butir item pernyataan yang valid dan memiliki koefisien reliabilitas sebesar 0,97. Sedangkan instrumen Kecerdasan Visual-Spasial Anak Usia Dini memiliki 27 butir item pernyataan yang valid dan memiliki koefisien reliabilitas sebesar 0,96. Berdasarkan hasil perhitungan analisis korelasi menggunakan Spearman Rank diperoleh harga rhohitung sebesar 0,64. Sedangkan, hasil perhitungan uji signifikansi korelasi menggunakan $t$ test diperoleh $t_{\text {hitung }}$ sebesar 3,99 dan $t_{\text {tabel }}$ pada taraf signifikansi 5\% dengan $\mathrm{db}=23$ sebesar 2,069. Karena $\mathrm{t}_{\text {hitung }}=3,99>\mathrm{t}_{\text {tabel }}=2,069$, maka dapat diinterpretasikan bahwa terdapat hubungan positif yang signifikan antara kegiatan bermain maze dengan kecerdasan visual-spasial anak usia dini.

Kata kunci: Anak Usia Dini, Maze, Visual-Spasial.

\begin{abstract}
This study aims to determine the reality of the relationship between maze play activities with early childhood visual-spatial intelligence in Group $A \mathrm{RA} A l-W$ afi Panyileukan Bandung. This research used was a quantitative approach with descriptive method. The subject in this research is 25 students of Group $A \mathrm{R} A$ Al-Wafi Panyileukan Bandung Period 2018/2019. This instrument used was an observation sheet that had been tested for validity using The Product Moment Correlation Formula and its reliability using The Alpha Formula. Maze Playing instrument has 36 valid statement items and has a reliability coefficient of
\end{abstract}


0,97. Whereas Early Childhood Visual-Spatial Intelligence instruments have 27 items of valid statements and have a reliability coefficient of 0,96. Based on the results of the calculation of correlation analysis using The Spearman Rank rho calculated value of 0,64. While the results of the calculation of the significance of the correlation test using $t$ test obtained $t_{\text {count }}$ of 3,99 and $t_{\text {table }}$ at a significance level Of $5 \%$ with $d f=23$ of 2,069. Because, $t_{\text {hitung }}=3,99>t_{\text {tabel }}=2,069$, that it can be interpreted there is significant positive relationship between maze play activities with visual-spatial intelligence of early childhood.

Keywords: early childhood, maze, visual-spatial.

\section{Pendahuluan}

Anak usia dini pada rentang usia 0-7 tahun berada dalam tahap eksplorasi, dimana tahap ini adalah tahapan yang tepat untuk mengenali berbagai macam potensi dan kecerdasan yang dimiliki oleh anak. Kecerdasan merupakan kemampuan tertinggi yang dimiliki oleh manusia yang dapat membantu seseorang dalam menghadapi berbagai permasalahan yang muncul dalam kehidupan. Gardner (Sujiono dan Sujiono, 2013: 55) membuat kriteria dasar untuk setiap kecerdasan. Lebih jelasnya, Gardner menamakannya dengan Teori Multiple Intellegence, dimana kecerdasan tersebut terbagi ke dalam delapan jenis yaitu: (1) kecerdasan linguistik; (2) kecerdasan logis-matematis; (3) kecerdasan kinestetik (olah tubuh); (4) kecerdasan musikal; (5) kecerdasan visual-spasial; (6) kecerdasan interpersonal; (7) kecerdasan intrapersonal; dan (8) kecerdasan naturalis.

Sebagian besar orang berpendapat bahwa anak yang cerdas adalah anak yang bisa menulis dan membaca dengan baik, hal itu tidak sepenuhnya salah akan tetapi, jika menilai kecerdasan anak hanya dengan kemampuan membaca dan menulisnya saja dan mengabaikan kecerdasan yang lain, hal ini juga kurang bijaksana. Salah satu kecerdasan yang sering diabaikan adalah kecerdasan visual-spasial. Menurut Idris (2014: 29-30) kecerdasan visualspasial adalah kemampuan untuk melihat dan mengamati dunia visual dan spasial secara akurat (cermat). Visual artinya gambar, sedangkan spasial adalah hal-hal yang berkenaan dengan ruang atau tempat.

Anak yang memiliki kecerdasan visual-spasial, akan lebih peka terhadap berbagai rangsangan visual dan spasial melebihi anak-anak normal pada umumnya. Anak tersebut akan menyukai hal-hal yang berkaitan dengan gambar, baik itu menggambar, mewarnai, membaca buku bergambar, serta mampu mengamati komponen-komponen gambar secara detail, sehingga mampu menuangkan kembali menjadi bentuk hasil karya. Anak yang memiliki kecerdasan ini juga bisa dengan mudah mengingat jalan yang pernah dilalui, serta mengingat 
dengan detail tata letak suatu objek. Oleh karena itu, Sujiono dan Sujiono (2013: 58) menguraikan salah satu cara untuk mengembangkan kecerdasan visual-spasial yaitu melalui permainan konstruktif dan kreatif.

Maze merupakan salah satu permainan konstruktif yang bertujuan untuk menentukan jalur yang tepat agar sampai ke tujuan yang telah ditetapkan. Menurut Rosidah (2014: 286) untuk menyelesaikan permainan ini, seseorang harus memilih jalan yang tepat agar bisa menemukan pintu keluar dan kesadaran akan arah. Selain itu, maze memiliki berbagai macam jenis dan bentuk. Salah satu maze yang sering digunakan untuk anak usia 4-5 tahun adalah basic maze dan match maze yang di dalamnya terdapat manik-manik berbagai macam warna, bentuk dan ukuran. Pada saat bermain maze anak dituntut untuk menggunakan kemampuan visual dan spasialnya agar anak mampu menemukan jalan keluar, memahami arah, sekaligus mampu mengklasifikasikan serta mencocokkan berbagai macam benda. Untuk itu, kegiatan bermain maze diduga erat kaitannya dengan visual-spasial terutama jenis spasial relation yakni kemampuan untuk mempersepsikan tentang posisi dan berbagai objek dalam ruang.

Berdasarkan studi pendahuluan, terdapat kesenjangan antara kegiatan bermain maze dengan kecerdasan visual-spasial. Anak mampu menyelesaikan permainan maze dengan baik disertai perolehan nilai rata-rata sebesar 79. Hal ini karena sebagian besar anak mampu memilih jalan yang tepat, mengklasifikasikan benda, memecahkan masalah, serta mencocokkan benda. Namun, lain halnya dengan kecerdasan visual-spasial. Beberapa anak kesulitan dalam membedakan arah kanan dan kiri, susah untuk mengekspresikan gagasan, dan sulit membedakan bentuk serta memilih kepingan yang cocok. Sehingga nilai rata-rata yang diperoleh sebesar 66 dan termasuk pada kategori cukup.

Oleh karena itu, berdasarkan fenomena di atas, penulis merasa tertarik untuk melakukan sebuah penelitian tentang Hubungan antara Kegiatan Bermain Maze dengan Kecerdasan Visual-Spasial Anak Usia Dini di Kelompok A RA Al-Wafi Panyileukan Bandung. Tujuan dari penelitian ini adalah untuk mengetahui seberapa besar hubungan antara kegiatan bermain maze dengan kecerdasan visual-spasial anak usia dini di Kelompok A RA Al-Wafi Panyileukan Bandung. Penelitian ini diharapkan mampu memberikan wawasan serta pengetahuan terkait hubungan antara kegiatan bermain maze dengan kecerdasan visual-spasial anak usia dini, serta implementasinya dalam pendidikan anak usia dini.

\section{Metodologi}


Penelitian ini menggunakan jenis pendekatan kuantitatif. Pendekatan kuantitatif adalah suatu proses untuk menemukan pengetahuan dengan menggunakan data berupa angka sebagai alat menganalisis keterangan mengenai apa yang ingin dikatahui (Sujarweni, 2014: 39). Selain penedekatan, penelitian pun tidak terlepas dari metode. Metode penelitian yang digunakan adalah penelitian deskriptif dengan desain penelitian korelasi. Adapun sumber data yang menjadi sasaran dalam penelitian ini adalah anak kelompok A RA Al-Wafi Panyileukan Bandung Tahun Ajaran 2018/2019.

Teknik pengumpulan data pada penelitian ini adalah teknik observasi. Observsi (observation) merupakan suatu teknik atau cara mengumpulkan data dengan jalan mengadakan pengamatan terhadap kegiatan yang sedang berlangsung (Sukmadinata, 2012: 220). Observasi ini dilakukan untuk memperoleh data dari variabel Kegiatan Bermain Maze dan Kecerdasan Visual-Spasial Anak Usia Dini di Kelompok A RA Al-Wafi Panyileukan. Untuk mengetahui tingkat kemampuan anak dalam kegiatan bermain maze dan kecerdasan viusal-spasial, digunakan lembar observasi dengan kriteria penilaian yang diadaptasi dari status perkembangan anak Suminah (2015: 5), yaitu: Berkembang Sangat Baik (BSB) diberikan skor 4, Berkembang Sesuai Harapan (BSH) diberikan skor 3, Mulai Berkembang (MB) diberikan skor 2, dan Belum Berkembang (BB) diberikan skor 1.

Sebelum lembar observasi digunakan dalam penelitian, terlebih dahulu dilakukan uji coba lembar observasi terhadap anak. Uji coba pada penelitian ini bertujuan untuk mengetahui tingkat validitas dan reliabilitas (Arikunto, 2010: 211-221). Berdasarkan hasil perhitungan validitas dan reliabilitas, instrumen Kegiatan Bermain Maže memiliki 36 butir item pernyataan yang valid dan memiliki koefisien reliabilitas sebesar 0,97. Sedangkan instrumen Kecerdasan Visual-Spasial Anak Usia Dini memiliki 27 butir item pernyataan yang valid dan memiliki koefisien reliabilitas sebesar 0,96.

Selanjutnya, teknik analisis data yang digunakan adalah teknik analisis korelasi. Korelasi adalah suatu teknik analisis data untuk mengukur tingkat koefisien hubungan dan pengaruh antara dua variabel (Hayati, 2013: 91). Sebelum masuk ke tahapan analisis korelasi, data harus diuji terlebih dahulu menggunakan Uji Normalitas dan Linieritas. Pengujian ini dilakukan untuk melihat apakah data yang dihasilkan berdistribusi normal dan regresinya linier atau tidak. Jika data dari salah satu atau kedua variabel berdistribusi normal dan regresinya linier, maka teknik korelasi yang digunakan adalah statistik parametris dengan rumus Korelasi Product Moment $(r x y)$. Akan tetapi, jika salah satu atau kedua variabel berdistribusi tidak 
normal, maka teknik korelasi yang digunakan adalah teknik statistik nonparametris dengan rumus Spearman Rank $(\rho)$.

\section{Hasil dan Diskusi}

Berdasarkan hasil perhitungan analisis parsial, sebagian besar anak di Kelompok A RA Al-Wafi Panyileukan Bandung mampu menyelesaikan permainan maze dengan sangat baik. Hal ini dilihat dari perolehan nilai rata-rata sebesar 84. Nilai tersebut didasarkan pada kemampuan anak dalam: 1) menemukan jalan yang tepat, bermain maze merupakan salah satu permainan teka-teki, dimana dalam permainan ini terdapat banyak sekali jalan berliku dan bercabang. Dalam permainan ini, anak harus selektif dan cermat dalam memilih jalan yang tepat; 2) memecahkan masalah, bermain maze dapat melatih anak untuk bisa memecahkan masalah, hal ini karena pada saat bermain maze anak diharuskan menemukan solusi untuk sampai ke tempat tujuan; 3) mengkalifikasikan benda, menurut Rosidah (2014: 286) kegiatan mengklasifikasikan benda ini, dapat mengembangkan aspek kognitif, serta menambah pengetahuan anak tentang macam-macam warna, bentuk, dan ukuran. Karena pada saat bermain maze, anak juga harus bisa mengelompokkan beberapa benda yang memiliki karakteristik yang sama; 4) mencocokkan benda, sama halnya dengan mengklasifikasikan benda, kegiatan mencocokkan benda juga bermanfaat untuk mengembangkan aspek kognitif serta kecerdasan visual (Musfiroh, 2005: 61). Pada saat memasangkan benda, anak akan dilatih kemampuan berpikir logis serta visualnya untuk dapat memilih kepala binatang yang cocok dengan badannya. 5) sadar akan arah, Pada saat bermain maze selain cermat memilih jalan anak juga dituntut untuk sadar akan arah. Sadar arah yang dimaksud di sini adalah arah kanan dan kiri, bukan arah barat, timur, utara, dan selatan, karena itu terlalu rumit jika diberikan kepada anak usia 4-5 tahun.

Sedangkan hasil analisis parsial tentang kecerdasan visual-spasial anak usia dini jenis spatial relation di Kelompok A RA Al-Wafi Panyileukan Bandung berkembang dengan baik. Hal ini dilihat dari perolehan nilai rata-rata sebesar 71. Nilai tersebut didasarkan pada kemampuan anak dalam: 1) mengingat arah dan jalan, Idris (2014: 30) berpendapat bahwa anak yang memiliki kecerdasan spatial relation akan mampu mengingat jalan yang pernah dilaluinya dengan baik. Anak tersebut akan mengingat tata letak, bangunan, serta arah dari jalan yang dilaluinya; 2) mengenal denah rumah, Anak yang memiliki kecerdasan spatial relation, biasanya peka terhadap posisi atau tata letak suatu objek. Oleh karena itu, mengenal denah rumah merupakan salah satu kegiatan yang dapat mengukur sejauh mana kemampuan 
anak dalam mengenal posisi rumah, bagian-bagian rumah, dan daerah sekitar rumah (Idris, 2014: 30); 3) menggambar dengan benar, Gardner (1993: 9) berpendapat bahwa anak yang memiliki kecerdasan ini akan lebih peka terhadap unsur pembentuk gambar seperti garis, bentuk, dan warna melebihi anak lain pada umumnya. Untuk itu anak tersebut mampu menggambar dengan benar dan detail; 4) membuat beberapa bangunan dalam berbagai media, melakukan permainan konstruktif seperti bermain lego dan balok merupakan salah satu cara untuk mengembangkan kecerdasan spatial relation pada anak. Anak yang gemar bermain lego dan balok akan lebih terampil dan terasah kecerdasan spatial relationnya (Sujiono dan Sujiono, 2013: 58-59); 5) bermain pu₹zle, salah satu karakteristik kecerdasan visual-spasial yang bisa dilihat pada anak usia dini adalah senang bermain puгzle. Bermain puzzle merupakan salah satu permainan teka-teki visual (membedakan suatu objek dengan objek yang lain).

Berdasarkan perhitungan uji normalitas dengan chi kuadrat pada variabel Kegiatan Bermain Mare, diperoleh mean $=81,2$ dan standar deviasi $=12,12$, nilai chi kuadrat $\left(\chi^{2}\right)$ hitung $=13,328$ dan chi kuadrat $\left(\chi^{2}\right)$ tabel $=12,592$ dengan $\mathrm{db}=6$ pada taraf signifikansi $5 \%$. Karena $\chi_{\text {hitung }}^{2}=13,328>\chi_{\text {tabel }}^{2}=12,592$, maka dapat disimpulkan bahwa data variabel Kegiatan Bermain Maze berdistribusi tidak normal. Sedangkan untuk perhitungan uji normalitas Variabel Kecerdasan Visual-Spasial Anak Usia Dini, diperoleh mean = 71,1 dan standar deviasi $=17,44$, nilai chi kuadrat $\left(\chi^{2}\right)$ hitung $=9,432$ dan chi kuadrat $\left(\chi^{2}\right)$ tabel $=$ 7,815 dengan $\mathrm{db}=3$ pada taraf signifikansi $5 \%$. Karena $\chi_{\text {hitung }}^{2}=9,432>\chi_{\text {tabel }}^{2}=7,815$, maka dapat disimpulkan bahwa data variabel Kecerdasan Visual-Spasial Anak Usia Dini berdistribusi tidak normal.

Setelah dilakukan perhitungan untuk pengujian normalitas pada setiap variabel, diperoleh hasil bahwa kedua variabel (Kegiatan Bermain Maze dan Kecerdasan Visual-Spasial Anak Usia Dini) berdistribusi tidak normal. Adapun untuk pengujian linieritas regresi sebagaimana yang terlampir diperoleh harga $\mathrm{F}_{\text {hitung }}=\mathbf{0 , 9 9}$ dan $\mathrm{F}_{\text {tabel }}$ pada taraf signifikansi 5\% dengan $\mathrm{db}=\frac{\text { pembilang }}{\text { penyebut }}=\frac{13}{10}=\mathbf{2 , 8 6}$. Karena $\mathrm{F}_{\text {hitung }}=0,99<\mathrm{F}_{\text {tabel }}=2,86$, maka dapat diinterpretasikan bahwa regresi $\mathrm{Y}$ atas $\mathrm{X}$ linier.

Dari hasil perhitungan koefisien korelasi antara Kegiatan Bermain Maze (variabel X) dengan Kecerdasan Visual-Spasial Anak Usia Dini (variabel Y) dari 25 responden yang diteliti, diperoleh angka koefisien korelasi sebesar 0.64. Nilai tersebut berada pada rentang 0,600 - 0,799 (kuat). Sedangkan untuk pengujian $t$ test diperoleh $t_{\text {hitung }}$ sebesar 3,99 dan $t_{\text {tabel }}$ pada taraf signifikansi 5\% dengan db $=23$ sebesar 2,069. Maka, $\mathrm{t}_{\text {hitung }}=3,99>\mathrm{t}_{\text {tabel }}=2,069$. 
Hal ini menunjukkan bahwa terdapat hubungan positif yang siginifikan antara kegiatan bermain maze dengan kecerdasan visual-spasial anak usia dini. Selain itu, kegiatan bermain maze memberikan kontribusi serta pengaruh sebanyak 41\% terhadap kecerdasan visualspasial anak usia dini. Dengan demikian, 59\% kecerdasan visual-spasial anak usia dini di Kelompok A RA Al-Wafi Bandung dipengaruhi oleh factor lain.

Dapat disimpulkan bahwa, terdapat korelasi yang positif antara kegiatan bermain maze dengan kecerdaan visual-spasial anak usia dini. Itu artinya, semakin tinggi kemampuan anak dalam bermain maze, maka semakin tinggi pula kecerdasan visual-spasialnya, atau semakin rendah kemampuan anak dalam bermain maze, maka semakin rendah pula kecerdasan visualspasialnya. Menurut Kusmayadi (2011: 36) anak yang memiliki kecerdasan visual-spasial cenderung senang berimajinasi, menggambar, mudah mengingat jalan serta bangunan yang ada di sekitar rumahnya. Hal ini sesuai dengan karakteristik yang terdapat pada maze, dimana maze itu sendiri adalah sebuah permainan berupa labirin yang di dalamnya terdapat jalan dan lorong yang berliku (Depdiknas, 2006: 549). Sehingga untuk mencari jalan keluar, anak dituntut menggunakan imajinasi serta kemampuan spasialnya untuk memahami arah dan mengenali jalan.

Maz̧e dalam penelitian ini dilengkapi dengan manik-manik berbagai macam warna dan bentuk. Hal ini bertujuan agar anak mampu mengkalsifikasikan serta mencocokkan benda, Menurut Rosidah (2014: 286) kegiatan mengklasifikasikan dan mencocokkan benda, dapat mengembangkan aspek kognitif, serta menambah pengetahuan anak tentang macam-macam warna, bentuk, dan ukuran. Adapun Musfiroh (2005: 61) berpendapat bahwa mencocokkan benda akan melatih kemampuan berpikir logis dan kecerdasan visual. Oleh karena itu kegiatan bermain maze dapat memberikan pengaruh serta kontribusi terhadap kecerdasan visual maupun spasial.

\section{Penutup}

Berdasarkan hasil penelitian, dapat disimpulkan bahwa: 1) kegiatan bermain maze di Kelompok A RA Al-Wafi Panyileukan Bandung berkualifikasi sangat baik; 2) kecerdasan visual-spasial anak usia dini di Kelompok A RA Al-Wafi Panyileukan Bandung berkualifikasi baik; 3) hubungan antara kegiatan bermain maze dengan kecerdasan visual-spasial anak usia dini berada pada kategori kuat. Hasil uji signifikansi menggunakan t test, diperoleh harga $t_{\text {hitung }}$ $=3,99>\mathrm{t}_{\mathrm{tabel}}=2,069$. Artinya Ha diterima, dengan kata lain terdapat hubungan positif yang siginifikan antara kegiatan bermain maze dengan kecerdasan visual-spasial anak usia dini. 
Ada beberapa saran yang dapat menjadi bahan masukan dan pertimbangan bagi pihakpihak terkait terutama pihak yang berkecimpung dalam ranah PAUD, diantaranya: 1) bagi pendidik, diharapkan mampu membuat inovasi yang baru dalam kegiatan bermain maze. Hal ini karena pemainan maze akan sangat berpengaruh terhadap kecerdasan visual-spasial anak; 2) bagi sekolah, diharapkan dapat memberikan fasilitas yang dapat menunjang kegiatan bermain maze, berilah anak ruang agar segala potensinya dapat terstimulus dengan baik, sehingga kecerdasan visual-spasial pun dapat berkembang secara optimal; 3) bagi penulis khususnya, dan umumnya bagi mahasiswa Program Studi Pendidikan Islam Anak Usia Dini, diharapkan dapat menghasilkan temuan baru yang akan menambah wawasan khazanah keilmuan tentang hubungan kegiatan bermain maze dengan kecerdasan visual-spasial anak usia dini.

\section{Daftar Pustaka}

Arikunto, S. (2002). Prosedur Penelitian. Jakarta : Rieneka Cipta.

Arikunto, S. (2010). Prosedur Penelitian Suatu Pendekatan Praktik. Jakarta: Rieneka Cipta.

Depdiknas. (2006). Kamus Besar Bahasa Indonesia. Jakarta: Balai Pustaka.

Hayati, T. (2013). Pengantar Statistika Pendidikan. Bandung: CV. Insan Mandiri.

Idris, M. H. (2014). Meningkatkan Kecerdasan Anak melalui Dongeng. Jakarta: PT Luxima Metro Media.

Kusmayadi, I. (2011). Membongkar Kecerdasan Anak (Mendeteksi Bakat \& Potensi Anak Sejak Dini). Jakarta: Gudang Ilmu.

Musfiroh, T. (2005). Bermain Sambil Belajar dan Mengasah Kecerdasan. Jakarta: Depdiknas.

Musfiroh, T. (2005). Pengembangan Kecerdasan Majemuk. Jakarta: Universitas Terbuka.

Rosidah, L. (2014). Peningkatan Kecerdasan Visual-Spasial Anak Usian Dini melalui Permainan Maze. Banten: Universitas Agung Tirtoyoso Banten.

Siswanto, I., \& Lestari, S. (2012). Panduan bagi Guru dan Orang Tua: Pembelajaran Atraktif dan 100 Permainan Kreatif untuk PAUD. Yogyakarta: CV. Andi.

Sujarweni, V. W. (2014). Metode Penelitian: Lengkap, Praktis, dan Mudah Dipahami. Yogyakarta: Pustaka Baru Press.

Sujiono, Y. N., \& Sujiono, B. (2013). Bermain Kreatif Berbasis Kecerdasan Jamak. Jakarta: PT Indeks.

Sukmadinata, N. S. (2012). Metode Penelitian Pendidikan. Bandung: PT Remaja Rosdakarya.

Suminah, E. d. (2015). Pedoman Penilaian Pembelajaran Pendidikan Anak Usia Dini. Jakarta: Kementrian Pendidikan dan Kebudayaan, Direktorat Pembinaan PAUD. 


\section{Biodata Penulis}

Yulia Rachmawati sebagai mahasiswi Jurusan Pendidikan Islam Anak Usia Dini, Fakultas Tarbiyah dan Keguruan Universitas Islam Negeri Sunan Gunung Djati Bandung. Lahir di Bandung pada Tanggal 01 Juli 1995. Penulis bertempat tinggal di Kp. Sirahranca RT/RW 002/009 Desa Banjaran Wetan Kecamatan Banjaran Kabupaten Bandung. 